\title{
T Lymphocyte Subsets in Patients with Newly Diagnosed Type 1 (Insulin-Dependent) Diabetes: A Prospective Study
}

\author{
K. Buschard ${ }^{1}$, C. Röpke², S. Madsbad ${ }^{3}$, J. Mehlsen $^{3}$ and J. Rygaard ${ }^{1}$ \\ ${ }^{1}$ Pathological-Anatomical Institute, Kommunehospitalet, Copenhagen, \\ ${ }^{2}$ Institute of Medical Anatomy, Department A, The Panum Institute, University of Copenhagen, and \\ ${ }^{3}$ Hvidøre Hospital, Klampenborg, Denmark
}

\begin{abstract}
Summary. T lymphocyte subsets in peripheral blood from 11 newly diagnosed Type 1 (insulin-dependent) diabetic patients were studied prospectively at three time intervals: as soon as possible after diagnosis, 3 weeks and 5 months later. Lymphocytes were marked with monoclonal OKT antibodies and examined in a fluorescence-activated cell sorter. The percentage of T lymphocytes (OKT 3) did not change significantly at the three study times. The percentage of helper/inducer $\mathrm{T}$ cells (OKT 4) was high the first week after diagnosis, but decreased at the 5-month examination $(p<0.05)$. The percentage of suppressor/cytotoxic T cells (OKT 8) was low at diagnosis but increased at 3 weeks $(p<0.02)$ and 5 months $(p<0.01)$. The ratio OKT 4/OKT 8 lymphocytes was 2.28 at diagnosis, decreasing to 1.77 at 3 weeks and 1.87 at 5 months, compared with 1.46
\end{abstract}

for 16 age-matched control subjects. There was no significant change in the absolute number of lymphocytes. It is concluded that the distribution of $T$ cell subsets was abnormal at the time of diagnosis, but changed towards normal within a few weeks, after which there was no significant change at 5 months. It is as yet unknown whether the high proportion of helper/inducer $\mathrm{T}$ cells and/or the low percentage of suppressor/cytotoxic T cells at diagnosis favour immune reactions involved in the pathogenesis of Type 1 diabetes.

Key words: $\mathrm{T}$ lymphocyte subpopulations, Type 1 diabetes, monoclonal antibodies, helper/inducer $T$ cells, suppressor/ cytotoxic $T$ cells, fluorescence-activated cell sorter.
This study concerns cells deriving from the thymus-dependent immune system in patients with Type 1 (insulin-dependent) diabetes. This part of the immune system has been implicated as an important pathogenetic factor in the development of Type 1 diabetes. By comparison with the normal mouse, the athymic (nude) mouse either does not become diabetic, or becomes much less severely diabetic, when exposed to the encephalomyocarditis virus [1-3] or low dose streptozotocin [4-6]. If anti-lymphocyte serum is given to spontaneously diabetic BB/W rats, these animals do not develop diabetes [7]. In patients with Type 1 diabetes, different antibodies against islet cells and/or beta cells have been found $[8,9]$, as have abnormal $\mathrm{K}$ cell levels [10], and $\mathrm{ab}$ normal suppressor cell activities [11]. Studies in vitro have shown that beta cells can be destroyed or their insulin secretion inhibited by administration of immunoglobulins or lymphocytes from Type 1 diabetic patients [12-14]. Immunological studies and, in particular, studies of the thymus-dependent system, therefore, seem relevant. Monoclonal antibodies allow separation of $T$ cells into subpopulations, which, in turn, allows more precise study of the $T$ cell distribution in different patient groups. In a previous study we have found that Type 1 diabetic patients display reduced numbers of suppressor/cytotoxic cells [15].

The aim of the present study was to conduct prospective examinations in patients with newly developed Type 1 diabetes to determine whether changes occur in the distribution of $\mathrm{T}$ cell subsets during the first months of disease from diagnosis to the remission period. Peripheral blood lymphocytes were studied in a fluorescence-activated cell sorter as soon as possible after diagnosis, after approximately 3 weeks of insulin treatment and finally after about 5 months, when Type 1 diabetic patients are usually in a relatively stable metabolic state.

\section{Materials and Methods}

\section{Patients}

Eleven patients with Type 1 diabetes were studied (eight men and three women of average age $26 \pm 3$ years; range: $14-39$ years). Clinical diagnosis of Type 1 diabetes rested on the following criteria: random blood glucose concentration $>12 \mathrm{mmol} / 1$, significant ketonuria ( $\geqslant$ 
Table 1. The percentage of OKT 3-, OKT 4- and OKT 8-positive lymphocytes in newly diagnosed Type 1 diabetic patients at the three study times

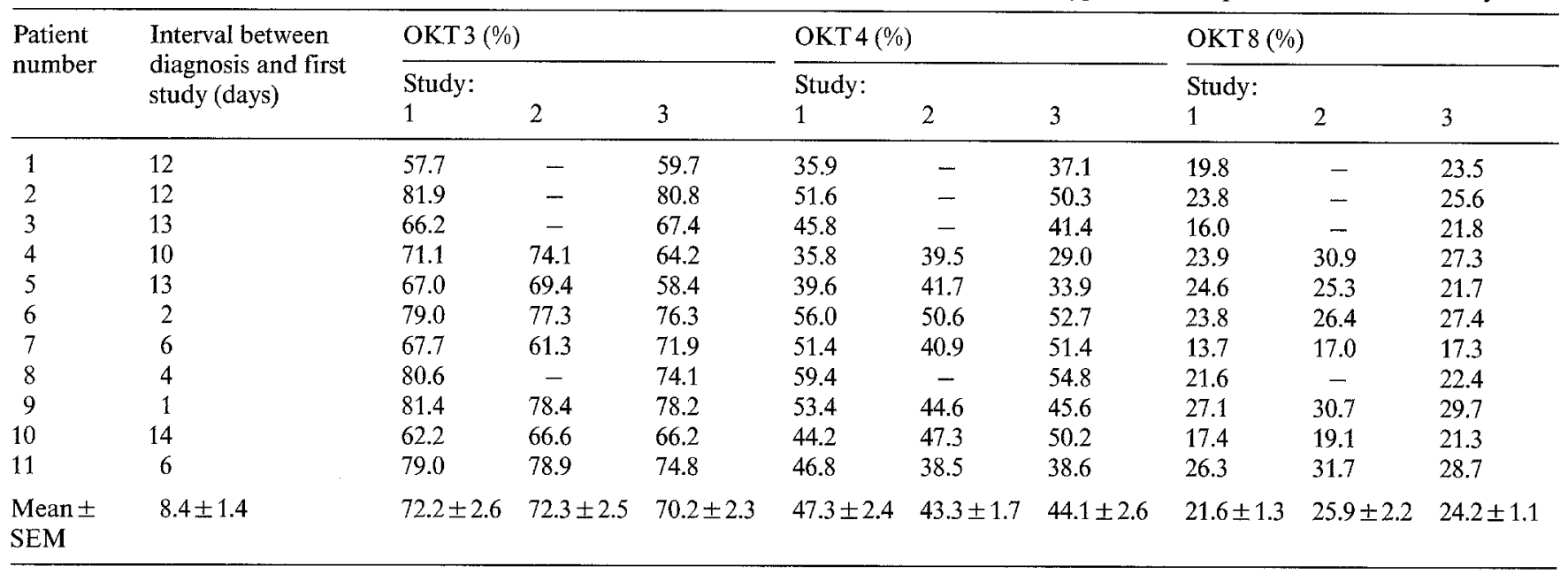

++ with Ketostix, Ames, Bridgend, UK) and glycosuria. Insulin treatment was started on the day of diagnosis and all patients have since continued with this treatment. The T cell subsets were examined on three occasions. The first examination was carried out within the first week (five patients, mean $4 \pm 1$ days) or in the second week (six patients, mean $12 \pm 1$ days) after diagnosis. The second examination took place on average $21 \pm 2$ days after starting insulin treatment ( 3 week study). The third examination was performed on average $158 \pm 9$ days after diagnosis ( 5 month study). All patients participated in the first and third study, seven in the second.

\section{Control Subjects}

The control group comprised eight men and eight women, all healthy without known allergies and without a family history of Type 1 diabetes. The average age was $25 \pm 1$ years (range $16-35$ years).

\section{T Cell Preparation and Analysis}

Peripheral blood lymphocytes were isolated by centrifugation on Ficoll-Hypaque (Nyegaard, Oslo, Norway) ad modum Böyum [16] and the cell concentration adjusted to $5 \times 10^{6} \mathrm{cells} / \mathrm{ml}$ in RPMI medium 1640 (Gibco, Paisley, UK) $+5 \%$ newborn calf serum. Cell suspensions $(200 \mu \mathrm{l})$ were incubated on ice for $30 \mathrm{~min}$ with $5 \mu \mathrm{OKT}$ antibody (Ortho Pharmaceuticals, Raritan, New Jersey, USA). After washing, $100 \mu 1$ FITC-labelled goat anti-mouse IgG antibody (Nordic Immunological Laboratories, Tilburg, The Netherlands), diluted 1: 30 , was added to $100 \mu \mathrm{l}$ of cell suspension and incubated on ice for $30 \mathrm{~min}$. The cells were then washed and resuspended in phosphate buffered saline $(1 \mathrm{ml})$ containing $3 \mathrm{mmol}$ EDTA. Cytofluorographic analysis of cell populations was performed on a fluorescence-activated cell sorter (FACS-III, Becton-Dickinson, Mountain View, California, USA). Only cells of a size corresponding to the lymphocyte population were analysed for fluorescence. For each monoclonal antibody investigated at least 50000 cells were examined. The background fluorescence profile determined after incubation with the fluoresceinconjugated goat anti-mouse IgG antibody only, was subtracted from the fluorescence profile detected with the monoclonal antibodies. The results were expressed as the percentage positive cells of the total number of cells counted. The following monoclonal antibodies were employed: OKT 3, OKT 4 and OKT 8, described to label all peripheral T lymphocytes, helper/inducer $\mathrm{T}$ cells and suppressor/cytotoxic $\mathrm{T}$ cells, respectively [17]. The OKT antibodies were obtained by fusion of non-secreting myeloma cells with spleen cells from mice immunized with human peripheral $T$ cells or thymocytes [18]. The absolute number of lymphocytes per $\mathrm{mm}^{3}$ was obtained by counting the total amount of leucocytes per $\mathrm{mm}^{3}$ followed by a differential count.

\section{Beta Cell Function}

Beta cell function was evaluated by measuring C-peptide after the patients had fasted overnight. Blood samples were taken from a peripheral vein $6 \mathrm{~min}$ after IV injection of $1 \mathrm{mg}$ of glucagon [19]. C-peptide concentrations were determined by the method of Heding, employing the antiserum M 1230 [20].

\section{Statistical Analyses}

Data are presented as mean \pm SEM. The significance of differences was evaluated by application of the Wilcoxon matched-pairs signedranks test or the Mann-Whitney U-test. The Spearman's rank correlation test was used for the calculation of the coefficient of correlation. The level of type 1 error $(2 \alpha)$ was set at 0.05 .

\section{Results}

The number of OKT 3 antibody labelled cells (T lymphocytes) from the individual patients is recorded in Table 1 as a percentage of the total amount of lymphocytes in peripheral blood. At the first study, the mean percentage was $72.2 \pm 2.6 \%$, at the second $72.3 \pm 2.5 \%$, and at the third $70.2 \pm 2.3 \%$. There were no significant differences within the patient group, nor by comparison with healthy control subjects $(72.2 \pm 1.4 \%)$.

OKT 4 marked lymphocytes (Table 1), reflecting the helper/inducer cell fraction, comprised $47.3 \pm 2.4 \%$ of all lymphocytes at diagnosis, falling to $43.3 \pm 1.7 \%$ at the second study and $44.1 \pm 2.6 \%(p<0.05)$ at the third study. Patients studied within 1 week of the start of insulin treatment displayed higher values $(53.4 \pm 2.1 \%)$ than patients studied between 1 and 2 weeks after diagnosis $(42.1 \pm 2.5 \%, p<0.02)$. It is unknown whether a statistically insignificant higher average age in the former group in comparison with the latter $(30 \pm 3$ versus $22 \pm$ 3 years, $p>0.10$ ) is of importance in interpreting the difference in the percentage of OKT 4 lymphocytes [21]. Only the diagnosis value in patients studied within 1 week was significantly higher than the value in the control group $(41.0 \pm 1.8 \%, p<0.005)$. 
Table 2. C-peptide values, insulin-dose and degree of glycaemic control in 11 newly diagnosed Type 1 diabetic patients at the three study times

\begin{tabular}{lcclcr}
\hline & $\begin{array}{l}\text { Interval after } \\
\text { diagnosis (days) }\end{array}$ & $\begin{array}{l}\text { C-peptide } \\
(\mathrm{pmol} / \mathrm{ml})\end{array}$ & $\begin{array}{l}\text { Insulin-dose } \\
\left(\mathrm{IU} \cdot \mathrm{kg} \mathrm{body} \mathrm{weight}{ }^{-1} \cdot 24 \mathrm{~h}^{-1}\right)\end{array}$ & $\begin{array}{l}\text { Glucosuria } \\
(\mathrm{g} / 24 \mathrm{~h})\end{array}$ & $\begin{array}{l}\text { Blood glucose } \\
(\mathrm{mmol} / \mathrm{l})\end{array}$ \\
\hline First study $(\mathrm{n}=11)$ & $8 \pm 1$ & $0.31 \pm 0.04$ & $0.33 \pm 0.04$ & $35 \pm 9$ & $11 \pm 1$ \\
Second study $(\mathrm{n}=7)$ & $21 \pm 2$ & $0.35 \pm 0.06$ & $0.33 \pm 0.03$ & $18 \pm 8$ & $9 \pm 1$ \\
Third study $(\mathrm{n}=11)$ & $158 \pm 9$ & $0.28 \pm 0.04$ & $0.32 \pm 0.03$ & $55 \pm 21$ & $10 \pm 1$ \\
\hline
\end{tabular}

Results are expressed as mean \pm SEM. $n$ represents the number of patients examined

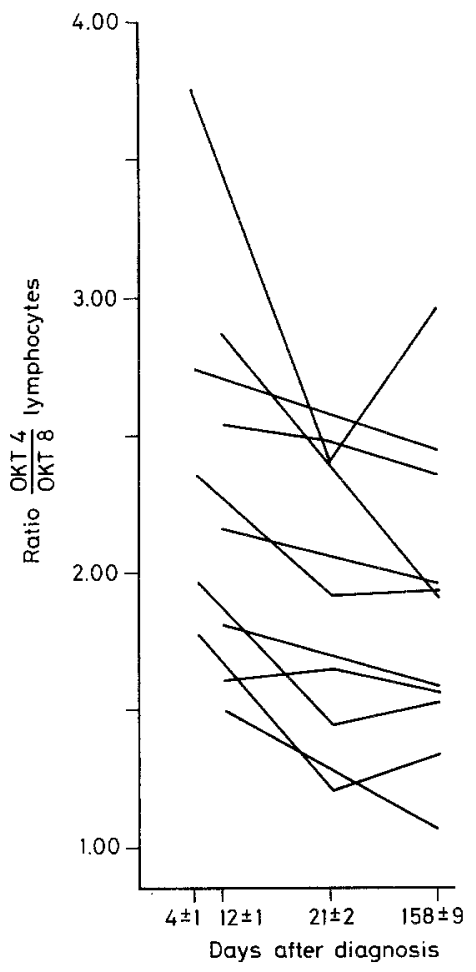

Fig. 1. The ratio between OKT 4- and OKT 8-positive lymphocytes in 11 newly diagnosed Type 1 diabetic patients. The lines connect results from individual patients obtained after various study times

OKT 8 marked lymphocytes (Table 1) reflecting the suppressor/cytotoxic cell fraction averaged $21.6 \pm 1.3 \%$ at the diagnosis study, increasing to $25.9 \pm 2.2 \%$ at the second study $(p<0.02)$ and $24.2 \pm 1.1 \%$ at the third study $(p<0.01)$. Both the diagnosis and the 5 month values were significantly lower than in the control group $29.5 \pm 1.3 \%(p<0.001$, and $p<0.01$, respectively $)$.

The ratio between OKT 4 and OKT 8 marked lymphocytes is shown in Figure 1. The mean value at diagnosis was $2.28 \pm 0.20$, falling to $1.77 \pm 0.19$ at the second study $(p<0.05)$, and $1.87 \pm 0.17$ at the 5-month study $(p<0.001)$. The ratio fell between the diagnosis study and the second study in six of seven patients, but in all 11 patients between the diagnosis and the 5 month studies. The diagnosis value was significantly higher than in the control group $(1.46 \pm 0.11, p<0.002)$. The absolute numbers of lymphocytes $/ \mathrm{mm}^{3}$ blood were $2.1 \pm 0.2 \times 10^{3}, 2.8 \pm 0.5 \times 10^{3}$, and $2.7 \pm 0.2 \times 10^{3}$, at the diagnosis and the second and third studies, respectively.
There were no significant differences between these values.

Table 2 shows the clinical data at the time of the three studies. The mean C-peptide values showed no significant differences between the examinations at diagnosis, after 3 weeks and after 5 months. Thus, beta cell function seems to have been stable over the period of the study. Also, insulin dosage was not significantly different at the three study times. Finally, average glucose excretion and mean blood glucose values showed no significant differences at the three examinations. No significant correlations were found between the percentage values of the different $T$ cell fractions, the ratio between OKT 4 and OKT 8 lymphocytes on the one hand and the recorded diabetological data on the other.

\section{Discussion}

This study has shown that the distribution of $\mathrm{T}$ cell subsets, identified by monoclonal OKT (4 and 8) antibodies, was abnormal at the time of diagnosis of Type 1 diabetes, but thereafter tended to change towards normal. This change, the fall in the helper/inducer T cell fraction and an increase in the suppressor/cytotoxic $T$ cell fraction, apparently occurred within a few weeks, after which there was no alteration up to 5 months.

The OKT antibody marked lymphocytes were counted in a fluorescence-activated cell sorter, which allows a high degree of accuracy. Very large numbers of cells are counted, background fluorescence is compensated, and the investigated cell population is defined precisely by light scatter and fluorescence settings. To calculate the percentage of lymphocytes positive to the respective antibodies, the fluorescence-activated cell sorter was gated to analyse only the lymphocyte population, which means that red blood cells, the majority of monocytes and granulocytes, isolated together with lymphocytes by the Ficoll-Hypaque centrifugation, as well as dead cells, were excluded. By this procedure, few large lymphocytes of a size corresponding to the majority of monocytes (the monocyte population) were not analysed. The importance of this is assumed to be negligible to the present type of quantitative study, and accordingly, this gating procedure is commonly used $[21,22]$. 
Based on functional studies using purified populations of the respective cell subset, it has been described that OKT 4 antibody labels for helper/inducer $T$ cells and OKT 8 for suppressor/cytotoxic T cells [17]. These specificities have been established through a number of studies and are commonly accepted [23]. Recently, it has been shown that a fraction of pokeweed mitogen-activated OKT 4 positive $T$ cells contains both helper and suppressor activity [24], and it seems likely that further research, e.g. with newly developed antibodies, will reveal additional functional subpopulations in the OKT 4 and OKT 8 positive T cell subsets. Such investigations may lead to a more detailed understanding of the presently shown alterations in the major $\mathrm{T}$ lymphocyte subsets in Type 1 diabetes.

Lymphocytes from patients with other diseases with suspected immune system involvement have been studied also by means of OKT antibodies [25], e.g. multiple sclerosis, where the OKT 4/OKT 8 lymphocyte ratio was found to be increased with reference to a healthy control group. The increase was greatest at times of exacerbation, which may indicate a positive correlation between OKT 4/OKT 8 ratios and disease activity [26]. Similarly, in this study of Type 1 diabetes, we found OKT 4/OKT 8 ratios were most elevated at the time of diagnosis, falling significantly thereafter at the 3-week and 5-month studies. It is difficult to document, but it is reasonable to assume that marked destruction of the beta cell mass occurs in the period before diagnosis. Judging from the stable beta cell function after diagnosis which continues in the remission period, disease activity appears to be limited during that span of time. In this connection, it should be noted also that islet cell antibodies are more often found at the time of diagnosis than subsequently [27].

It is possible that the degree of metabolic control can influence the distribution of $\mathrm{T}$ cell subsets. However, no significant differences were found in the glycosuria and fasting blood glucose values at the different study times. In an earlier study of suppressor cell activity related to the efficiency of glycaemic control, it was found that great improvement of control had no effect on suppressor cell function during a period of a few weeks [28].

Concerning the suppressor $\mathrm{T}$ lymphocytes included in the fraction of OKT 8 cells, some functional studies of suppressor cell activity have been made in Type 1 diabetic patients. Horowitz et al. [29], Buschard et al. in newly diagnosed patients [11], Ledermann et al. [30], and Fairchild et al. [31], have all found reduced suppressor cell activity, while Slater et al. [32] found normal or slightly increased activity in patients with disease duration of 2 or more years. In a previous prospective study, we found that a reduced suppressor cell activity at the time of diagnosis improved significantly at examination approximately 5 months later [33], in good accordance with the findings in this present study.

The helper/inducer (OKT 4) fraction of the T lym- phocytes was increased at the time of diagnosis in comparison with the 5-month study. It is as yet unknown whether the high amount of helper/inducer $T$ cells and/or the low percentage of suppressor/cytotoxic $T$ cells at diagnosis favour immune reactions involved in the pathogenesis of Type 1 diabetes.

Acknowledgements. We are indebted to Mrs. A. Hansen for excellent technical assistance. The study was supported by grants from Novo's Fond and the Danish Medical Research Council, grant no. 512-20708.

\section{References}

1. Buschard K, Rygaard J, Lund E (1976) The inability of a diabetogenic virus to induce diabetes mellitus in athymic (nude) mice. Acta Path Microbiol Scand Sect C 84: 299-303

2. Jansen FK, Thurneyssen O, Müntefering H (1979) Virus induced diabetes and the immune system II - Evidence for an immune pathogenesis of the acute phase of diabetes. Biomedicine 31:1-2

3. Buschard K, Hastrup N, Rygaard J (1983) Virus-induced diabetes mellitus in mice and the thymus-dependent immune system. Diabetologia $24: 42-46$

4. Like AA, Rossini AA (1976) Streptozotocin-induced pancreatic insulitis: new model of diabetes mellitus. Science 193: 415-417

5. Buschard K, Rygaard J (1978) Is the diabetogenic effect of streptozotocin in part thymus-dependent? Acta Path Microbiol Scand Sect C 86: 23-27

6. Paik S-G, Fleischer N, Shin S-I (1980) Insulin-dependent diabetes mellitus induced by subdiabetogenic doses of streptozotocin: obligatory role of cell-mediated autoimmune processes. Proc Natl Acad Sci USA 77: 6129-6133

7. Like AA, Rossini AA, Guberski DL, Appel MC, Williams RM (1979) Spontaneous diabetes mellitus: reversal and prevention in the $\mathrm{BB} / \mathrm{W}$ rat with antiserum to rat lymphocytes. Science 206: $1421-1423$

8. Bottazzo GF, Florin-Christensen A, Doniach D (1974) Islet-cell antibodies in diabetes mellitus with autoimmune polyendocrine deficiencies. Lancet 2:1279-1283

9. Lernmark $\AA$, Freedman ZR, Hofmann C, Rubenstein AH, Steiner DF, Jackson RL, Winter RJ, Traisman HS (1978) Islet-cell-surface antibodies in juvenile diabetes mellitus. $\mathbf{N}$ Engl $\mathbf{J}$ Med 299: 375-380

10. Pozzilli P, Gorsuch A, Sensi M, Bottazzo GF, Cudworth AG (1979) Evidence for raised K-cell levels in Type I diabetes. Lancet 2: $173-175$

11. Buschard K, Madsbad S, Rygaard J (1980) Depressed suppressor cell activity in patients with newly diagnosed insulin-dependent diabetes mellitus. Clin Exp Immunol 41: 25-32

12. Dobersen MJ, Scharff JE, Ginsberg-Fellner F, Notkins AL (1980) Cytotoxic autoantibodies to beta cells in the serum of patients with insulin-dependent diabetes mellitus. $\mathrm{N}$ Engl $\mathbf{J}$ Med 303: 1493-1498

13. Kanatsuna T, Lernmark Å, Rubenstein AH, Steiner DF (1981) Block in insulin release from column-perifused pancreatic betacells induced by islet cell surface antibodies and complement. Diabetes 30: 231-234

14. Boitard C, Debray-Sachs M, Pouplard A, Assan R, Hamburger J (1981) Lymphocytes from diabetics suppress insulin release in vitro. Diabetologia 21: 41-46

15. Buschard K, Röpke C, Madsbad S, Mehlsen J, Sørensen TB, Rygaard J (1983) Alterations of peripheral T-lymphocyte subpopulations in patients with insulin-dependent (type 1) diabetes mellitus. $\mathrm{J}$ Clin Lab Immunol 10: 127-131

16. Böyum A (1968) Isolation of mononuclear cells and granulocytes from human blood. Isolation of mononuclear cells by one centrifugation, and of granulocytes by combining centrifugation and sedimentation at $1 \mathrm{~g}$. Scan J Clin Lab Invest 21 (suppl 97): 77-89 
17. Reinherz EL, Schlossman SF (1980) The differentiation and function of human T lymphocytes. Cell 19: 821-827

18. Kung PC, Goldstein G, Reinherz EL, Schlossman SF (1979) Monoclonal antibodies defining distinctive human $T$ cell surface antigens. Science 206: 347-349

19. Faber OK, Binder C (1977) C-peptide response to glucagon. A test for the residual beta-cell function in diabetes mellitus. Diabetes 26: $605-610$

20. Heding LG (1975) Radioimmunological determination of human C-peptide in serum. Diabetologia 11: $541-548$

21. Nagel JE, Chrest FJ, Adler WH (1981) Enumeration of T lymphocyte subsets by monoclonal antibodies in young and aged humans. J Immunol 127: 2086-2088

22. Hoffman RA, Kung PC, Hansen WP, Goldstein G (1980) Simple and rapid measurement of human $\mathrm{T}$ lymphocytes and their subclasses in peripheral blood. Proc Natl Acad Sci USA 77: 4914-4917

23. Chatenoud L, Bach JF (1981) Review article: human T cell markers in health and disease. Hum Lymphoc Differ 1: 131-148

24. Thomas $\mathrm{Y}$, Rogozinski L, Irigoyen $\mathrm{OH}$, Shen $\mathrm{HH}$, Talle MA, Goldstein G, Chess L (1982) Functional analysis of human T cell subsets defined by monoclonal antibodies. V.Suppressor cells within the activated $\mathrm{OKT} 4^{+}$population belong to a distinct subset. J Immunol 128: 1386-1390

25. Bach M-A, Bach J-F (1981) The use of monoclonal anti-T cell antibodies to study $\mathrm{T}$ cell imbalances in human diseases. Clin Exp Immunol 45: 449-456

26. Bach M-A, Phan-Dinh-Tuy F, Tournier E, Chatenoud L, Bach J-F, Martin C, Degos J-D (1980) Deficit of suppressor T cells in active multiple sclerosis. Lancet 2: 1221-1223
27. Lendrum R, Walker G, Cudworth AG, Theophanides C, Pyke DA, Bloom A, Gamble DR (1976) Islet-cell antibodies in juvenile diabetes mellitus of recent onset. Lancet 2: 1273-1276

28. Buschard K, Madsbad S, Krarup T, Rygaard J (1982) Glycaemic control and suppressor cell activity in patients with insulin-dependent diabetes mellitus. Clin Exp Immunol 48: 189-195

29. Horowitz SD, Borcherding W, Bargman GJ (1977) Suppressor T cell function in diabetes mellitus. Lancet 2: 1291

30. Lederman MM, Ellner JJ, Rodman HM (1981) Defective suppressor cell generation in juvenile onset diabetes. J Immunol 127: 2051-2055

31. Fairchild RS, Kyner JL, Abdou NI (1982) Specific immunoregulation abnormality in insulin-dependent diabetes mellitus. J Lab Clin Med 99: 175-186

32. Slater LM, Murray SL, Kershnar A, Mosier MA (1980) Immunological suppressor cell activity in insulin dependent diabetes. $\mathbf{J}$ Clin Lab Immunol 3: 105-109

33. Buschard K, Madsbad S, Rygaard J (1982) Suppressor cell activity in patients with newly diagnosed insulin-dependent diabetes mellitus: A prospective study. J Clin Lab Immunol 8: 19-23

Received: 5 November 1982

and in revised form: 15 June 1983

Dr. Karsten Buschard

Pathological-Anatomical Institute

Kommunehospitalet

DK-1399 Copenhagen K

Denmark 